Available online at https://jurnal.stmikroyal.ac.id/index.php/jurdimas

\title{
PEMBERDAYAAN MASYARAKAT DAN IDENTIFIKASI FAKTOR RISIKO KESEHATAN DI DUSUN JARANAN
}

\author{
Septian Emma Dwi Jatmika \\ Kesehatan Masyarakat, Universitas Ahmad Dahlan Yogyakarta \\ email: septianemma@ikm.uad.ac.id
}

\begin{abstract}
Jaranan Hamlet has never identified health risk factors related to PHBS and KADARZI. The purpose of this service is to find out the lowest indicators of PHBS and KADARZI. The methods used are program socialization, data analysis, and problem priority determination, Hamlet Community Deliberation (MMD), intervention, and partner participation. The results obtained, the priority problem in RT 10 and 11 Dusun Jaranan is the low number of people who do not do physical activity every day. It was agreed to be held together and blood pressure measurement before and after exercise. People are very enthusiastic and experience a decrease in blood pressure after participating in gymnastics. It is hoped that this community service program in the form of community empowerment can be used as a motivation for the community to routinely do gymnastics which can be beneficial for residents.
\end{abstract}

Keywords: identification of health risk factors; community empowerment; gymnastics

\begin{abstract}
Abstrak: Dusun Jaranan belum pernah dilakukan identifikasi faktor risiko kesehatan terkait dengan PHBS dan KADARZI. Tujuan pengabdian ini untuk mengetahui indikator dari PHBS dan KADARZI yang paling rendah. Metode yang digunakan yaitu sosialisasi program, analisis data dan penentuan prioritas masalah, Musyawarah Masyarakat Dusun (MMD), intervensi, dan partisipasi mitra. Hasil yang didapatkan, prioritas masalah di RT 10 dan 11 Dusun Jaranan yaitu masih rendahnya masyarakat yang tidak melakukan aktifitas fisik setiap hari. Disepakati untuk diadakan senam bersama dan pengukuran tekanan darah sebelum dan sesudah senam. Masyarakat sangat antusisas dan mengalami penurunan tekanan darah setelah mengikuti senam. Diharapkan dengan adanya program pengabdian berupa pemberdayaan masyarakat ini dapat dijadikan motivasi masyarakat untuk rutin mengadakan senam yang dapat bermanfaat bagi warga.
\end{abstract}

Kata kunci: identifikasi faktor risiko kesehatan; pemberdayaan masyarakat; senam

\section{PENDAHULUAN}

Di Indonesia upaya peningkatan perilaku sehat di rumah tangga belum menunjukkan hasil optimal. Hal ini dapat dilihat dari hasil Riset Kesehatan Dasar (RISKESDAS) tahun 2013 yang menunjukkan bahwa di Indonesia, rumah tangga yang mempraktikkan Perilaku Hidup Bersih dan Sehat (PHBS) men- capai 32,3\% (Badan Penelitian dan Pengembangan Kesehatan RI, 2013). Sedangkan di Daerah Istimewa Yogyakarta (DIY) persentase rumah tangga yang menerapkan PHBS (Perilaku Hidup Bersih dan Sehat) pada tahun 2018 adalah sebanyak $45 \%$ (Dinas Kesehatan DIY, 2019). Hal ini seperti pada penelitian sebelumnya bahwa PHBS di tatanan rumah tangga masyarakat Desa 
Available online at https://jurnal.stmikroyal.ac.id/index.php/jurdimas

Parang Baddo juga masih dibawah standar target Kementerian Kesehatan, yaitu 70\% (Natsir, 2019).

Angka persentase tersebut menunjukan bahwa masih rendahnya rumah tangga yang menerapkan PHBS, sehingga perlu dilakukan peningkatan melalui sosialisasi secara terus menerus dan berkelanjutan serta pemberdayaan kelompok masyarakat. Sosialisasi /penyuluhan efektif dalam meningkatkan pengetahuan masyarakat tentang PHBS. Penyuluhan yang dilakukan di Desa Jayaraga dapat meningkatkan pengetahuan warga tentang PHBS tatanan rumah tangga yaitu dari $40 \%$ warga yang memahami sebelum penyuluhan menjadi 90\% warga memahaminya (Shalahuddin, Rosidin, \& Nurhakim, 2018).

Hal tersebut merupakan salah satu faktor yang berpengaruh terhadap derajat kesehatan masyarakat selain lingkungan, pelayanan kesehatan, dan faktor keturunan. Pada kegiatan pengabdian sebelumnya bahwa pendidikan PHBS yang dilakukan kepada anak-anak sekolah memberikan manfaat peningkatan pengetahuan tentang PHBS, sehingga diharapkan dapat dipraktikan dalam kehidupan sehari-hari (Sanjaya, Fara, \& Sagita, 2019)

Upaya pencegahan yang paling penting dan termasuk kedalam pencegahan primer yaitu perilaku manusia untuk melaksanakan PHBS. Upaya PHBS jika tidak dilakukan oleh setiap anggota keluarga dan masing masing individu akan menjadi faktor dalam timbulnya berbagai penyakit. Sebaliknya, jika upaya PHBS dilaksanakan dengan baik, maka dapat mencegah timbulnya penyakit. Penelitian yang telah dilakukan sebelumnya bahwa semakin tinggi nilai PHBS, semakin rendah kejadian penyakit diare, demam berdarah dan angka bebas larva (Raksanagara \& Raksanagara, 2015).

Selain masalah yang berkaitan dengan perilaku masyarakat untuk hidup bersih dan sehat, permasalahan gizi di Indonesia pun juga masih menjadi sorotan Permasalahan gizi pertama di indonesia meliputi kekurangan energi protein (KEP), kekurangan vitamin A (KVA), gangguan akibat kekurangan yodium (GAKY), anemia gizi besi (ABG), dan gizi lebih (obesitas). Saat ini di Indonesia tengah menghadapi dua masalah gizi atau biasa disebut dengan masalah gizi ganda, yaitu belum selesainya masalah gizi buruk/kurang ditambah adanya peningkatan kasus gizi berlebih (obesitas) (Wijayanti \& Nindya, 2017).

Pada penelitian sebelumnya didapatkan hasil bahwa perilaku keluarga sadar gizi berpengaruh terhadap status gizi Balita. Perlunya perhatian terhadap gizi balita karena mereka masih dalam tahap pertumbuhan dan perkembangan. Maka dari itu perlunya masyarakat untuk sadar akan gizi (Rodiah, Arini, \& Syafei, 2018). Dusun Jaranan terletak di Desa Banguntapan, Kecamatan Banguntapan, Kabupaten Batul.

Berdasarkan hasil studi pendahuluan yang dilakukan di RT 10 dan RT 11 Dusun Jaranan belum pernah dilakukan identifikasi faktor risiko kesehatan terkait dengan PHBS dan KADARZI. Maka dari itu pengusung tertarik melakukan pendataan indikator PHBS di rumah tangga dan KADARZI untuk mengetahui indikator mana yang belum baik sehingga dapat dilakukan intervensi kesehatan untuk mengatasi permasalahan kesehatan di Dusun Jaranan. 
Available online at https://jurnal.stmikroyal.ac.id/index.php/jurdimas

\section{METODE}

Kegiatan pengabdian dilakukan di RT 10 dan RT 11 Dusun Jaranan, Banguntapan, Bantul. Ada 127 responden dalam kegiatan pengabdian ini. Cara pengolahan data dengan melakukan analisis univariat untuk melihat distribusi frekuensi masing-masing RT.

Berdasarkan pada prioritas permasalahan yang dihadapi mitra dan target luaran yang ingin dicapai maka disusun metode pelaksanaan dalam pengabdian masyarakat.

\section{Sosialisasi Program Pengabdian}

Sosialisasi program pengabdian diberikan kepada kelompok masyarakat yang didampingi oleh petugas kesehatan Puskemas Banguntapan III, Kepala Dukuh, tokoh masyarakat Dusun Jaranan dan kader kesehatan Posyandu Raflesia 4 di RT 10 dan 11. Pengusung melibatkan mahasiswa Fakultas Kesehatan Masyarakat semester 6 dalam kegiatan pengabdian.

\section{Analisis Data dan Penentuan Priori- tas Masalah}

Sebelum dilakukan analisis data dan prioritas masalah kesehatan yang ada di Dusun Jaranan, mahasiswa PBL melakukan pengambilan data masyarakat RT 10 dan 11 Dusun Jaranan terkait 10 indikator PHBS dan 5 indikator KADARZI. Analisis data menggunakan metode USG (Urgent, Seriousness, Growth) lalu ditentukan 3 prioritas masalah dengan skor tertinggi dari semua indikator.

\section{Musyawarah Masyarakat Dusun (MMD)}

Musyawarah Masyarakat Dusun dilakukan setelah selesai melakukan pendataan. Musyawarah ini bertujuan untuk mendiskusikan hasil pendataan yang didapat dan menentukan satu prioritas masalah. Kemudian bersama-sama masyarakat merencanakan kegiatan /intervensi yang akan diberikan.

\section{Intervensi}

Intervensi merupakan kegiatan yang dilakukan dengan memberikan perlakuan kepada masyarakat untuk mengatasi permasalahan kesehatan yang terjadi di masyarakat. Intervensi dilakukan setelah mendapat kesepakatan bersama dari kelompok masyarakat.

\section{Partisipasi Mitra dalam Pelaksanaan Program}

Partisipasi mitra dalam pelaksanaan program adalah sebagai partisipan aktif pemberdayaan mayarakat melalui peningkatan perilaku hidup bersih dan sehat dalam pengendalian faktor risiko kesehatan. Dalam program ini tugas dan tanggung jawab mitra adalah sebagai berikut :

1. Mitra menyediakan waktu untuk bersama-sama dalam program pemberdayaan masyarakat di lokasi mitra.

2. Mitra mengikuti kegiatan yang diselenggarakan pengusul.

3. Mitra merupakan penanggung jawab kegiatan di lokasi pengabdian.

4. Mitra menyebarluaskan informasi dan pengetahuan kepada kelompok masyarakat yang lain

\section{PEMBAHASAN}

Kegiatan pengabdian diawali degan mengurus perizinan yang dilakukan oleh pengusung bersama tim mahasiswa kepada Kepala Dukuh Dusun Jaranan pada tanggal 29-30 Januari 2020. Kemudian melakukan koordinasi yang 
Available online at https://jurnal.stmikroyal.ac.id/index.php/jurdimas

dihadiri oleh Petugas Kesehatan Puskemas Banguntapan III, Kepala Dusun, Kader kesehatan, perwakilan Ibu-ibu PKK, Ketua RT dan RW guna sosialisasi program. Sosialisasi ini dilakukan pada tanggal 1 Februari 2020 di rumah Kepala Dusun Jaranan. Setelah diberikan sosialisasi dan izin untuk melakukan kegiatan pengabdian di wilayah RT 10 dan 11 Dusun Jaranan, tim pengusung mulai melakukan pengambilan data dibantu oleh kader kesehatan. Pengambilan data dilaksanakan selama tanggal 2-6 Februari 2020. Pada gambar 1 merupakan hasil dokumentasi saat melakukan sosialisasi kegiatan pengabdian, dan hasil yang didapat disajikan dalam bentuk tabel 1 .

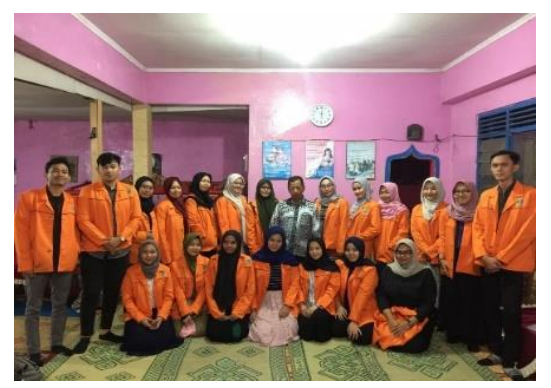

Gambar 1. Sosialisasi Kegiatan

Pengabdian
Pada tabel 1 dapat diketahui pencapaian terendah dari masing-masing RT yaitu pada indikator mengonsumsi suplemen gizi. Suplemen gizi yang dimaksud berupa tablet tambah darah dan kapsul vitamin A dosis tinggi. Berdasarkan kelima indikator KADARZI dapat disimpulkan persentase warga dengan KADARZI di RT 10 dan RT 11. Persentase tersebut disajikan pada Tabel 2 dapat diketahui bahwa warga RT 11 Dusun Jaranan memiliki persentase lebih tinggi, yaitu terdapat $79 \%$ warga yang sudah menerapkan KADARZI. Semakin baik penerapan perilaku Kadarzi maka semakin baik status gizi balita. Penelitian sebelumnya bahwa terdapat hubungan antara perilaku Kadarzi dengan status gizi balita $\mathrm{BB} / \mathrm{U}$ (Wijayanti \& Nindya, 2017).

Selain indikator KADARZI, pengusung juga mengambil data tentang PHBS di RT 10 dan RT 11. Persentase indikator PHBS di RT 10 dan RT 11 Dusun Jaranan disajikan pada Tabel 3.

Tabel 1. Persentase Indikator KADARZI di RT 10 dan 11 Dusun Jaranan

\begin{tabular}{clcc}
\hline No & Indikator & RT 10 & RT 11 \\
\hline 1 & Menimbang berat badan secara teratur & $100 \%$ & $100 \%$ \\
\hline 2 & Memberi ASI Ekslusif & $69 \%$ & $100 \%$ \\
\hline 3 & Makan Beraneka ragam & $86 \%$ & $92 \%$ \\
\hline 4 & Menggunakan Garam Ber-yodium & $98 \%$ & $96 \%$ \\
\hline 5 & Mengonsumsi Suplemen Gizi & $63 \%$ & $91 \%$ \\
\hline
\end{tabular}

Tabel 2. Persentase Warga dengan KADARZI di RT 10 dan 11 Dusun Jaranan

\begin{tabular}{ccll}
\hline No & Keterangan & RT 10 & RT 11 \\
\hline 1 & KADARZI & $69 \%$ & $79 \%$ \\
\hline 2 & Tidak KADARZI & $31 \%$ & $21 \%$ \\
\hline
\end{tabular}


Available online at https://jurnal.stmikroyal.ac.id/index.php/jurdimas

Tabel 3. Persentase Indikator PHBS

\begin{tabular}{clcc}
\hline No & \multicolumn{1}{c}{ Indikator } & RT 10 & RT 11 \\
\hline 1 & Persalinan ditolong oleh tenaga kesehatan & $100 \%$ & $100 \%$ \\
\hline 2 & Memberi bayi ASI Ekslusif & $69 \%$ & $100 \%$ \\
\hline 3 & Menimbang bayi dan balita setiap bulan & $100 \%$ & $100 \%$ \\
\hline 4 & Menggunakan air bersih & $100 \%$ & $100 \%$ \\
\hline 5 & Mencuci tangan dengan air bersih dan mengalir dengan sabun & $79 \%$ & $87 \%$ \\
\hline 6 & Menggunakan jamban sehat & $94 \%$ & $100 \%$ \\
\hline 7 & Memberantas jentik di rumah & $90 \%$ & $93 \%$ \\
\hline 8 & Melakukan aktivitas fisik setiap hari & $58 \%$ & $68 \%$ \\
\hline 9 & Makan sayur dan buah setiap hari & $82 \%$ & $77 \%$ \\
\hline 10 & Tidak merokok di dalam rumah & $33 \%$ & $64 \%$ \\
\hline
\end{tabular}

Berdasarkan tabel 3 dapat diketahui bahwa pencapaian terendah dari masing-masing RT yaitu pada indikator tidak merokok di dalam rumah. Merokok memiliki dampak yang buruk bagi kesehatan, seperti kerusakan paruparu dan kanker. Selain itu perokok pasif pun juga mendapat dampak apabila ada yang merokok di dalam rumah. Rumah merupakan tempat berlindung bagi keluarga, termasuk dari paparan asap rokok. Perokok pasif harus berani menyuarakan haknya untuk tidak menghirup asap rokok (Depkes RI, 2014).

Tabel 4. Persentase Warga ber-PHBS

\begin{tabular}{llll}
\hline No & Keterangan & RT 10 & $\begin{array}{l}\text { RT } \\
\mathbf{1 1}\end{array}$ \\
\hline 1 & Ber-PHBS & $30 \%$ & $43 \%$ \\
\hline 2 & Tidak Ber-PHBS & $70 \%$ & $57 \%$ \\
\hline
\end{tabular}

Berdasarkan tabel 4 dapat diketahui bahwa warga RT 11 Dusun Jaranan memiliki persentase lebih tinggi, yaitu terdapat $43 \%$ warga yang sudah menerapkan perilaku hidup bersih dan sehat. Kebersihan akan berdampak pada kesehatan seseorang. Menurut Lesman, pengabdian yang telah dilakukan sebelumnya di Desa Mansalong dan Desa Tanjung Hulu untuk mewujudkan desa bersih dan mandiri dapat dilakukan dengan melakukan pemberdayaan masyarakat seperti senam, jogging, penyuluhan, dan pengelolaan sampah untuk meningkatkan kepedulian dan kesadaran masyarakat untuk ber-PHBS (Lesman \& Agang, 2019). Kemudian data yang telah didapatkan diolah sehingga didapatkan 3 prioritas masalah. Selain melihat dari persentase data, penentuan prioritas juga ditentukan melalui metode USG (Urgent, Seriousness, Growth) yang disepakati bersama tokoh masyarakat yang ada di Dusun Jaranan. Prioritas masalah kesehatan diRT 10 dan RT 11 Dusun Jaranan disajikan pada Tabel 5.

Tabel 5. Prioritas masalah di RT 10 dan 11 Dusun Jaranan

\begin{tabular}{clcccccc}
\hline No & Indikator & \% & U & S & G & Skor & Rank \\
\hline 1 & Melaku kan aktivitas fisik setiap hari & 63 & 5 & 5 & 4 & 14 & 1 \\
\hline 2 & Tidak merokok di dalam rumah & 49 & 5 & 4 & 3 & 12 & 2 \\
\hline 3 & Me ngonsumsi suplemen gizi & 77 & 4 & 3 & 2 & 9 & 3 \\
\hline
\end{tabular}


Available online at https://jurnal.stmikroyal.ac.id/index.php/jurdimas

Berdasarkan tabel 5 didapatkan hasil bahwa indikator melakukan aktivitas fisik menempati urutan pertama. Artinya masalah aktivitas fisik menjadi prioritas utama yang harus perlu dicari solusi untuk mengatasinya. Dalam MMD, Peserta musyawarah sepakat untuk mengadakan senam aerobik untuk warga. Berikut foto dokumentasi saat pengambilan data bersama Kader Kesehatan.

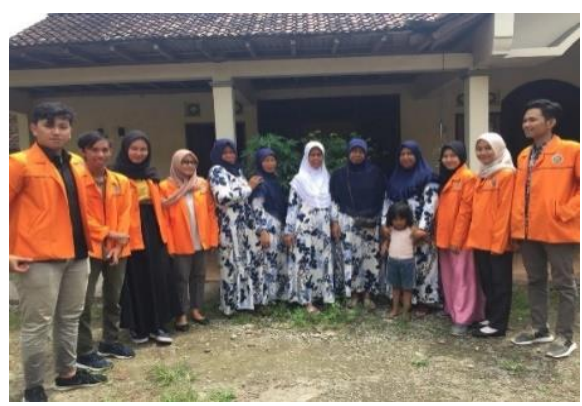

Gambar 2. Persiapan Pengambilan Data Bersama Kader Kesehatan

Senam merupakan salah satu aktifitas fisik yang dapat dilakukan oleh masyarakat. Senam dapat dilakukan bersama-sama untuk menambah semangat masyarakat untuk melakukan aktivitas fisik secara rutin. Hal ini juga dapat meningkatkan kerjasama antarwarga. Sehingga dapat tercipta lingkungan yang harmonis di dalam masyarakat. Hal ini juga akan mempermudah untuk meningkatkan pemberdayaan di masyarakat. Berikut adalah foto dokumentasi saat melakukan senam bersamamasyarakat.



Gambar 3. Senam Bersama Masyarakat
Tim pengusung melakukan pengukuran tekanan darah peserta sebelum dan sesudah senam. Pengukuran tekanan darah dilakukan oleh mahasiswa Fakultas Kesehatan Masyarakat dan mahasiswa Farmasi dengan meng-gunakan alat tensi meter digital sebanyak 4 alat tensi. Usai kegiatan senam berakhir, tim mahasiswa membagikan air mineral serta doorprice kepada ibu-ibu sebagai bentuk hiburan setelah dilakukan senam bersama. Sesudah melakukan senam dan pembagian doorprize, ibu-ibu diarahkan kembali untuk mengukur tekanan darah agar dapat mengetahui efek dari kegiatan senam terhadap tekanan darah. Dalam pengukuran tensi sebelum dan sesudah didapatkan hasil bahwa, beberapa ibuibu ada yang mengalami kenaikan tekanan darah yaitu sebanyak 3 orang dan penurunan tekanan darah sebanyak 11 orang. Kegiatan senam tersebut diharapkan dapat meningkatkan aktifitas fisik pada masyakarat khususnya di RT 10 dan 11 Dusun Jaranan. Penelitian sebelumnya yang telah dilakukan didapatkan hasil bahwa ada pengaruh senam lansia aerobic low impact training terhadap penurunan tekanan darah pada penderita hipertensi, dimana senam lansia aerobic low impact training mampu menurunkan tekanan darah lansia di panti Griya Usila Santo Yosef Surabaya (Widjayanti, Silalahi, \& Merrianda, 2019).

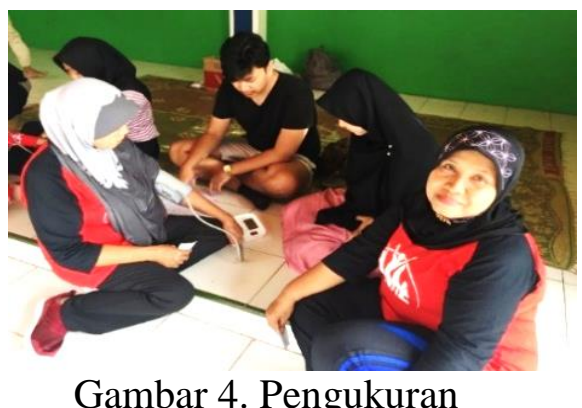

Tekanan Darah 
Available online at https://jurnal.stmikroyal.ac.id/index.php/jurdimas

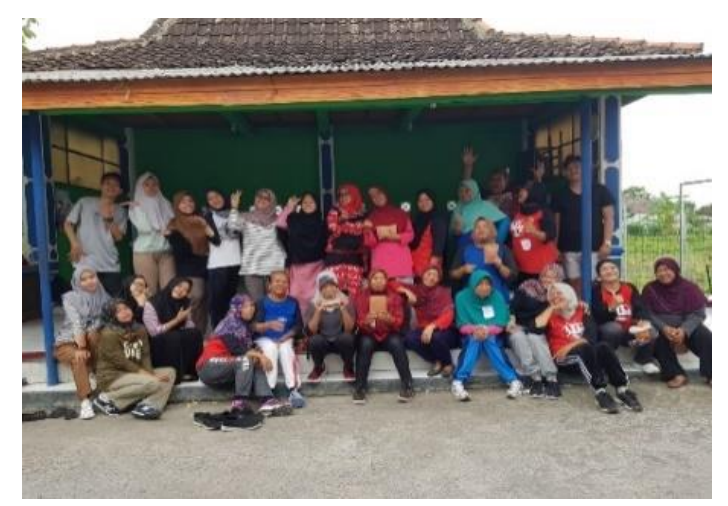

Gambar 5. Foto Bersama Setelah Senam

\section{SIMPULAN}

Berdasarkan hasil pelaksanaan program kegiatan yang dilaksanakan oleh pengusung ditemukan yaitu masih rendahnya masyarakat untuk melakukan aktivitas fisik setiap hari. Sehingga tim pengusung dan masyarakat sepakat untuk melakukan intervensi guna mengatasi masalah yang ada. Intervensi yang dilakukan berupa senam dan pengukuran tekanan darah sebelum dan sesudah senam. Hasil yang didapatkan masyarakat antusias mengikuti kegiatan senam dan mayoritas masyarakat mengalami penurunan tekanan darah setelah mengikuti senam.

\section{UCAPAN TERIMA KASIH}

Terima kasih kami ucapkan kepada Lembaga Penelitian dan Pengabdian Masyarakat (LPPM) Universitas Ahmad Dahlan, Yogyakarta yang telah mendanai program Pengabdian Kepada Masyarakat 2020, dan terima kasih kepada masyarakat Dusun Jaranan, Banguntapan, Bantul yang telah berpartisipasi dalam kegiatan pengabdian pada masyarakat ini.

\section{DAFTAR PUSTAKA}

Badan Penelitian dan Pengembangan Kesehatan RI. (2013). Hasil Riskesdas 2013. Jakarta.

Depkes RI. (2014). Booklet Perilaku Hidup Bersih dan Sehat di Rumah Tangga. Jakarta: Departemen Kesehatan RI.

Dinas Kesehatan DIY. (2019). Profil Kesehatan D.I Yogyakarta tahun 2018. In Departemen Kesehatan RI. Retrieved from http://www.dinkes.jogjaprov.go.id/dow nload/download/27.

Kemenkes RI. (2018). Mengenal Jenis Aktivitas Fisik. Retrieved from http://promkes.kemkes.go.id/content/?p $=8807$

Lesman, H., \& Agang, M. W. (2019). Pemberdayaan Mahasiswa Dengan Masyarakat Desa Mansalong dan Desa Tanjung Hulu Kabupaten Nunukan Melalui Optimalisasi Potensi Lokal Dengan Pendekatan Revolusi Mental dalam Mewujudkan Desa Bersih Dan Mandiri. Jurnal Pengabdian Masyarakat Borneo, 3(November 2018), 61-66.

Natsir, M. F. (2019). Perilaku Hidup Bersih Dan Sehat (PHBS) Pada Tatanan Rumah Tangga Masyarakat Desa Parang Baddo. Jurnal Nasional Ilmu Kesehatan ( JNIK ), 1(3), 54-59.

Raksanagara, A. S., \& Raksanagara, A. (2015). Perilaku Hidup Bersih dan Sehat Sebagai Determinan Kesehatan yang Penting pada Tatanan Rumah Tangga di Kota Bandung. Jurnal Sistem Kesehatan, 1(38), 30-34.

Rodiah, Arini, N., \& Syafei, A. (2018). Pengaruh Perilaku Keluarga Sadar Gizi (Kadarzi) terhadap Status Gizi Balita. Jurnal Ilmu Kesehatan Masyarakat, 7(3), 174-184. https://doi.org/10.33221/jikm.v7i3.126

Sanjaya, R., Fara, Y. D., \& Sagita, Y. D. (2019). PENDIDIKAN PERILAKU HIDUP BERSIH DAN SEHAT (PHBS) DI SEKOLAH. Jurnal Pengabdian Kepada Masyarakat 
Jurdimas (Jurnal Pengabdian Kepada Masyarakat) Royal

Vol. 4 No. 1, Januari 2021, hlm.13-20

DOI: https://doi.org/10.33330/jurdimas.v4i1.588

Available online at https://jurnal.stmikroyal.ac.id/index.php/jurdimas

Ungu, 1(1), 55-60. Retrieved from https://puskesmasbatuputihberau.word press.com/promkes/info-

kesehatan/perilaku-hidup-bersih-dansehat-phbs-di-sekolah/

Shalahuddin, I., Rosidin, U., \& Nurhakim, F. (2018). Pendidikan/Penyuluhan Kesehatan tentang PHBS Tatanan Rumah Tangga. Media Karya Kesehatan, 1(2), 127-134. https://doi.org/10.24198/mkk.v1i2.168 59

Widjayanti, Y., Silalahi, V., \& Merrianda, P.
(2019). Pengaruh Senam Lansia Aerobic Low Impact Training Terhadap Penurunan Tekanan Darah Pada Lansia Penderita Hipertensi. Jurnal Keperawatan Muhammadiyah, 4(2), 137-142.

Wijayanti, S., \& Nindya, T. S. (2017). Hubungan Penerapan Perilaku Kadarzi ( Keluarga Sadar Gizi ) dengan Status Gizi Balita di Kabupaten Tulungagung. Amerta Nutr, 379-388. https://doi.org/10.20473/amnt.v1.i4.20 17.378-388 